\title{
Morphometric Attributes and their Controlling Elements in Himalayan Snow Trout, Schizothorax labiatus inhabiting Vishav Stream of South Kashmir, India
}

\author{
Mohammad Yasir Arafat ${ }^{1 *}$ and Yahya Bakhtiyar ${ }^{2}$ \\ 'Department of Zoology, School of Life Sciences, University of Kashmir, Srinagar - 190006, \\ Jammu and Kashmir, India; yasirt99@gmail.com \\ ${ }^{2}$ Department of Zoology, University of Kashmir, Srinagar - 190006, Jammu and Kashmir, India; \\ yahya.bakhtiyar@gmail.com
}

\begin{abstract}
The morphometric analysis was carried out in indigenous cyprinid food fish, Schizothorax labiatus (a species of snow trout) collected from Vishav stream, a perennial cold water stream of Kashmir valley, India, wherein various morphometric characters viz., Total Length (TL), Standard Length (SL), Fork Length (FL), Pre-dorsal Length (PDL), Pre-pectoral Length (PPL), Pre-pelvic Length (PPeL), Pre-anal Length (PAL), Anal Fin Length (AL), Head Length (HL), Height of Dorsal Fin (HOD), Snout Length (SnL), Body Depth (BD), Eye Diameter (ED), Inter Orbital Length (IOL), Caudal Fin Length (CL) and Caudal Depth (CD) of 104 fish specimens were measured, correlated and analysed. The morphometric data was calculated in the percentage of total length except SnL, ED and IOL which were calculated in the percentage of HL. The result revealed that the correlation coefficient ranged from 0.770 to 0.995 in proportion to TL and 0.706 to 0.859 in proportion to HL which indicates that all the morphometric characters are highly correlated. All the correlations were significant at the level of $\mathrm{p}<0.01$. During the investigation, the results revealed that in the $\%$ of $\mathrm{TL}$, 8 characters were found to be genetically controlled 4 characters as intermediate and none character as environmentally controlled one. In the $\%$ of $\mathrm{HL}, 1$ character was found to be included in intermediate character, 2 characters in environmentally controlled characters and none in purely genetically controlled one. As revealed by the regression analysis of different morphometric characters in proportion to TL, the maximum growth was obtained for FL $(b=0.9664)$ and the minimum growth was obtained for $\mathrm{AL}(\mathrm{b}=0.0655)$ and in proportion to $\mathrm{HL}$, the maximum growth was obtained for IOL $(b=0.4689)$ and the minimum growth was obtained for ED $(b=0.0852)$.
\end{abstract}

Keywords: Correlation Coefficient, Kashmir, Morphometric Analysis, Schizothorax labiatus, Vishav Stream

\begin{abstract}
Abbreviations: Total Length (TL), Standard Length (SL), Fork Length (FL), Pre-dorsal Length (PDL), Pre-pectoral Length (PPL), Pre-pelvic Length (PPeL), Pre-anal Length (PAL), Anal Fin Length (AL), Head Length (HL), Height of Dorsal Fin (HOD), Snout Length $(\mathrm{SnL})$, Body Depth (BD), Eye Diameter (ED), Inter Orbital Length (IOL), Caudal Fin Length (CL) and Caudal Depth (CD).
\end{abstract}

\section{Introduction}

The much prized indigenous food fishes of Kashmir valley taxonomically under family cyprinidae include Schizothoracine species viz. Schizothorax niger, S. labiatus, S. esocinus, S. plagiostomus and S. curvifrons. Since the dawn of animal taxonomy, biologists began to analyse and draw conclusions regarding the variations in morphological parameters among biological specimens and subsequently came up with their proper identification as identification is the basic step and feature to study any species ${ }^{1,2}$. A high degree of variation in morphology is seen within and among populations of fishes than other vertebrates as they are more susceptible elements of variation with respect to environmental parameters ${ }^{3-7}$. Some biological events such as isolation of spawning areas, hydrography and disturbance in migratory patterns pose a considerable effect on morphological variations in fishes ${ }^{8,9}$. Since different aquatic environments provide different ecological niches ${ }^{10}$ and the variations induced by such environmental

${ }^{*}$ Author for correspondence 
factors may be an adaptive response in order to maintain relative fitness ${ }^{11}$, which is known to be as phenotypic plasticity. Thus, in order to effectively manage the fishery resources of any water body, it is very much indispensable to identify the explored fish species. According to morphological systematics, morphometric and meristic counts are the simplest and easiest way to distinguish the disparity among the fish species and can complement other approaches such as DNA barcoding and protein studies towards successful taxonomic processes. The kind of morphometric disparity between the stocks can provide the basis for stock structure and make us aware about the environmentally induced variations in the stock ${ }^{12}$. Some workers opine that the morphometric analysis successfully determine the controlling factors or elements of morphometry simply on the basis of range difference as, genetically controlled (narrow range), environmentally controlled (vast range) and intermediate characters (moderate range) ${ }^{3,13,14}$.

Since the Vishav stream is one of the large and important left bank perennial tributary of river Jhelum of the Kashmir valley and is famous for harbouring a number of indigenous Schizothoracine fish fauna and hence forms the livelihood components of large number of local populace located along the bank of this very stream.

The subfamily Schizothoracine is one of the much prized food fish among the indigenous fish fauna of Kashmir valley and a considerable similarity among the stocks of indigenous Schizothoracine has been noticed in different water bodies of Kashmir valley. They are commonly known by the name as 'snow trouts' because of their dominance in snow fed and the torrential mountain streams of Himalaya and central Asia ${ }^{15}$. Schizothorax labiatus, locally known as 'Chush gad' is one among these snow trouts inhabiting the Vishav stream and forms one of the main component of the fish catch of this stream. As per the available literature, there seems lack of detailed information on the morphometrics of S. labiatus in some important hill streams like Vishav stream. Therefore, keeping in view the morphological disparity and food value of S. labiatus, an attempt was made to take such a problem in hand for the proper morohometric analysis of S. labiatus from Vishav stream which subsequently will generate a baseline data for the comparison of morphometrical variations with respect to stream habitats and subsequently its proper identification, conservation and management.

\section{Materials and Methods}

\subsection{Study Area}

The study area selected for the present research work is the famous left bank perennial tributary of river Jhelum of the Kashmir valley called the "Vishav stream". This very steam which covers an area of about $1083.4 \mathrm{~km}^{2}$ and situated between

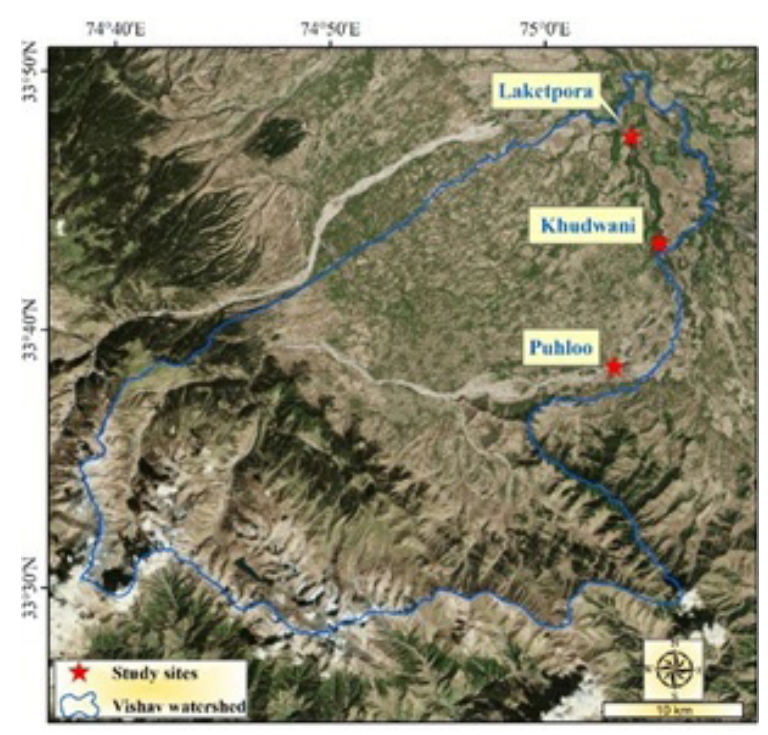

Figure 1. Outline map of the Vishav stream with three study sites.

$33^{\circ} 39^{\prime}$ to $33^{\circ} 65^{\prime} \mathrm{N}$ latitude and $74^{\circ} 35^{\prime}$ to $75^{\circ} 11^{\prime} \mathrm{E}$ longitudes, stems from a glacier fed stream called 'Teri' at the base of Kousarnag at an altitude of about 3840 (masl) on the northern face of Pir panjal range of Kashmir Himalayas and occupies the South-Eastern part of Kashmir valley, wherein during its course it follows a zigzag pattern, making its movement first in north direction, then takes a south-easterly course and finally flows in a laminar way in north-westerly direction till it mixes with the river Jhelum at Niayun ${ }^{16}$.

\subsection{Sampling}

Regular sampling of fish specimen from Vishav stream was carried out on monthly basis for a period of one year from October 2017 to September 2018 from different sampling stations (Figure 1) with the help of expert fishermen. Total of 104 fish samples were collected ranging from $29 \mathrm{~g}$ to $547.5 \mathrm{~g}$ in weight and $15.2 \mathrm{~cm}$ to $36 \mathrm{~cm}$ in length, by using fishing gears like cast nets of mesh size $2 \mathrm{~cm} \times 2 \mathrm{~cm}$ and $6 \mathrm{~cm} \times 6 \mathrm{~cm}$.

\subsection{Identification}

The fish specimens were taken to laboratory and the mucus and dust was removed and then subsequently identified by following the standard taxonomic keys ${ }^{17-19}$. The samples were also preserved in $10 \%$ formaldehyde for future reference.

\subsection{Morphometry}

For morphometry, digital slide vernier calliper (Aero Space) accurate to $0.1 \mathrm{~cm}$ and for weight, digital precision balance (Kerro BL50001) accurate to $0.1 \mathrm{~g}$ were used. The morphometry were done by following ${ }^{20-22}$. The morphometric 
characters studied were, Total Length (TL), Standard Length (SL), Fork Length (FL), Pre-dorsal Length (PDL), Pre-pectoral Length (PPL), Pre-pelvic Length (PPeL), Pre-anal Length (PAL), Anal Fin Length (AL), Head Length (HL), Height of Dorsal Fin (HOD), Snout Length (SnL), Body Depth (BD), Eye Diameter (ED), Inter Orbital Length (IOL), Caudal Fin Length (CL) and Caudal Depth (CD) (Figure 2). The morphometric variables were calculated in the percentage of total length except SnL, ED and IOL which were calculated in the percentage of HL.

\subsection{Data Analysis}

The data generated during the study was employed for statistical analysis like mean, Standard Deviation (SD), range difference, Variance (V), Coefficient of Variation (COV), correlation coefficient ( $r$ ) and regression, whereas the values of correlation coefficient and regression equations are based on the original readings. The statistical analysis were done using the excel2016 and Minitab version 18. The resulting morphometric data generated after statistical analysis was then classified on the basis of range into three groups of characters viz. genetically controlled (range $=1-9.9 \%$ ), intermediate $($ range $=10-14.9$ or $<15 \%$ ) and environmentally controlled (range $=>15 \%$ ) characters ${ }^{14}$.

\section{Results and Discussions}

The morphometric data analysed statistically revealed some significant results as depicted in (Table 1 and Figure 3), wherein, in $\%$ of TL, the maximum SD and maximum variance is seen in case of PAL and the minimum SD and minimum variance is seen in case of CD. While as in \% of HL, the maximum SD and maximum variance is seen in case of IOL and the minimum $\mathrm{SD}$ and minimum variance is seen in case of ED.

Regarding the correlation analysis of various morphometric characters, it is revealed that the correlation coefficient ranged from 0.770 to 0.995 in proportion to TL and 0.706 to 0.859 in proportion to HL which indicates that all the morphometric characters are highly correlated. In proportion to TL, the high correlation is seen in case of SL $(r=0.995)$ and the least correlation is seen in case of CL $(r=0.770)$. While as, in proportion to HL, the high correlation is seen in case of $\mathrm{SnL}$ $(r=0.859)$ and the lowest correlation is seen in case of ED $(r=0.706)$. All the correlations were significant at the level of $\mathrm{p}<0.01$, indicating that all the morphometric characters increase in the direct proportion with each other.

Regarding the controlling elements/factors of various morphometric characters, the range value given in the (Table 1) clearly indicated that in the \% of TL there are, 8 genetically controlled characters viz. SL, HL, PDL, PPL, AL, HOD, CL and CD; 4 intermediate characters viz. FL, PPeL, PAL and BD and none environmentally controlled characters. In the $\%$ of $\mathrm{HL}$, 1 character viz. ED was found to be included in intermediate category and 2 characters viz. SnL and IOL in environmentally controlled characters.

The regression analysis of different morphometric characters in proportion to TL, revealed that the maximum growth was obtained for FL $(b=0.9664)$ and the minimum growth was obtained for AL $(b=0.0655)$. In proportion to $\mathrm{HL}$, the maximum growth was obtained for IOL $(b=0.4689)$ and the minimum growth was obtained for $\mathrm{ED}(\mathrm{B}=0.0852)$.

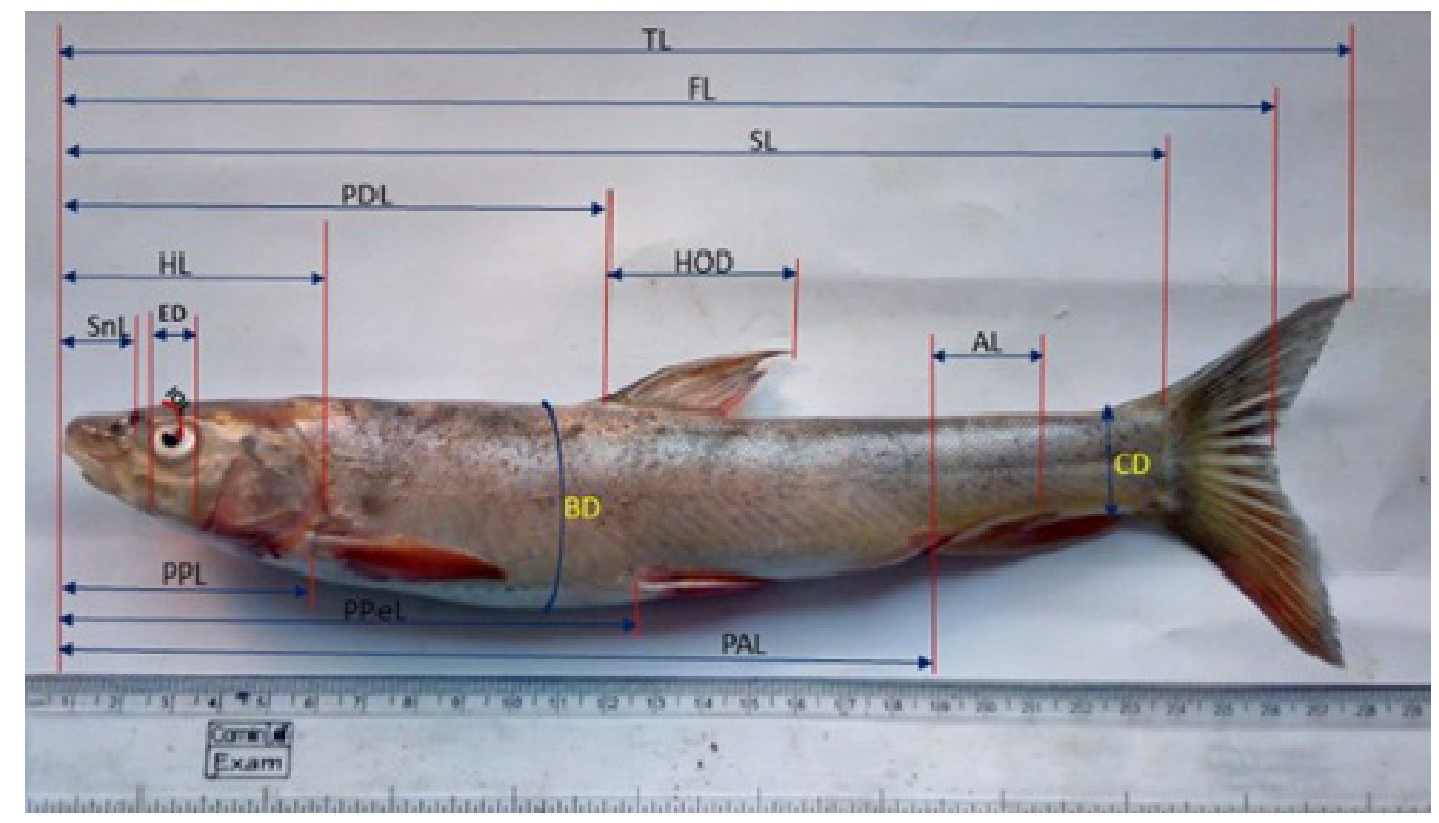

Figure 2. Outline of various morphometric characters of Schizothorax labiatus. 
Table 1. Analysis of morphometric characters

\begin{tabular}{|c|c|c|c|c|c|c|c|c|c|}
\hline \multicolumn{10}{|c|}{ In the $\%$ of TL } \\
\hline Parameters & Min & Max & Range & Mean & S.D & Variance & C.O.V & $\mathbf{r}$ & $\begin{array}{l}\text { Regression Equation } \\
\qquad(\mathrm{Y}=\mathrm{a}+\mathrm{bx})\end{array}$ \\
\hline SL & 80.26 & 88.74 & 8.48 & 84.46 & 1.67 & 2.78 & 0.02 & 0.995 & $S L=0.8876 x-1.1196$ \\
\hline FL & 88.89 & 99.65 & 10.76 & 92.83 & 1.86 & 3.46 & 0.02 & 0.993 & $\mathrm{FL}=0.9664 \mathrm{x}-0.9938$ \\
\hline HL & 11.67 & 20.96 & 9.29 & 17.82 & 1.56 & 2.42 & 0.09 & 0.857 & $\mathrm{HL}=0.1596 \mathrm{x}+0.4852$ \\
\hline PDL & 38.00 & 46.09 & 8.09 & 41.61 & 1.36 & 1.86 & 0.03 & 0.979 & $\mathrm{PDL}=0.4176 \mathrm{x}-0.0382$ \\
\hline PPL & 12.90 & 20.77 & 7.86 & 17.32 & 1.47 & 2.15 & 0.08 & 0.857 & $\mathrm{PPL}=0.1493 \mathrm{x}+0.6246$ \\
\hline PPeL & 37.96 & 50.00 & 12.04 & 43.79 & 1.74 & 3.03 & 0.04 & 0.970 & $\mathrm{PPeL}=0.4286 \mathrm{x}+0.2445$ \\
\hline PAL & 61.11 & 73.05 & 11.94 & 65.44 & 2.22 & 4.94 & 0.03 & 0.984 & $\mathrm{PAL}=0.7004 \mathrm{x}-1.1947$ \\
\hline $\mathrm{AL}$ & 4.56 & 11.24 & 6.68 & 5.78 & 0.80 & 0.64 & 0.14 & 0.840 & $\mathrm{AL}=0.0655 \mathrm{x}-0.2049$ \\
\hline $\mathrm{BD}$ & 11.41 & 25.00 & 13.59 & 17.03 & 1.85 & 3.43 & 0.11 & 0.829 & $\mathrm{BD}=0.1612 \mathrm{x}+0.2396$ \\
\hline HOD & 11.24 & 17.50 & 6.26 & 13.83 & 1.46 & 2.13 & 0.11 & 0.776 & $\mathrm{HOD}=0.0898 \mathrm{x}+1.2656$ \\
\hline $\mathrm{CL}$ & 11.26 & 20.71 & 9.45 & 15.59 & 1.72 & 2.95 & 0.11 & 0.770 & $\mathrm{CL}=0.1126 \mathrm{x}+1.1268$ \\
\hline $\mathrm{CD}$ & 6.29 & 10.85 & 4.56 & 8.00 & 0.71 & 0.51 & 0.09 & 0.851 & $C D=0.0735 x+0.1698$ \\
\hline \multicolumn{10}{|c|}{ In the $\%$ of $\mathrm{HL}$} \\
\hline SnL & 24.00 & 42.86 & 18.86 & 33.85 & 3.42 & 11.67 & 0.10 & 0.859 & $S n L=0.3465 x-0.0379$ \\
\hline ED & 14.06 & 25.71 & 11.65 & 18.78 & 2.37 & 5.62 & 0.13 & 0.706 & $E D=0.0852 x+0.474$ \\
\hline IOL & 49.02 & 97.14 & 48.12 & 64.57 & 8.90 & 79.22 & 0.14 & 0.721 & $\mathrm{IOL}=0.4689 \mathrm{x}+0.8166$ \\
\hline
\end{tabular}
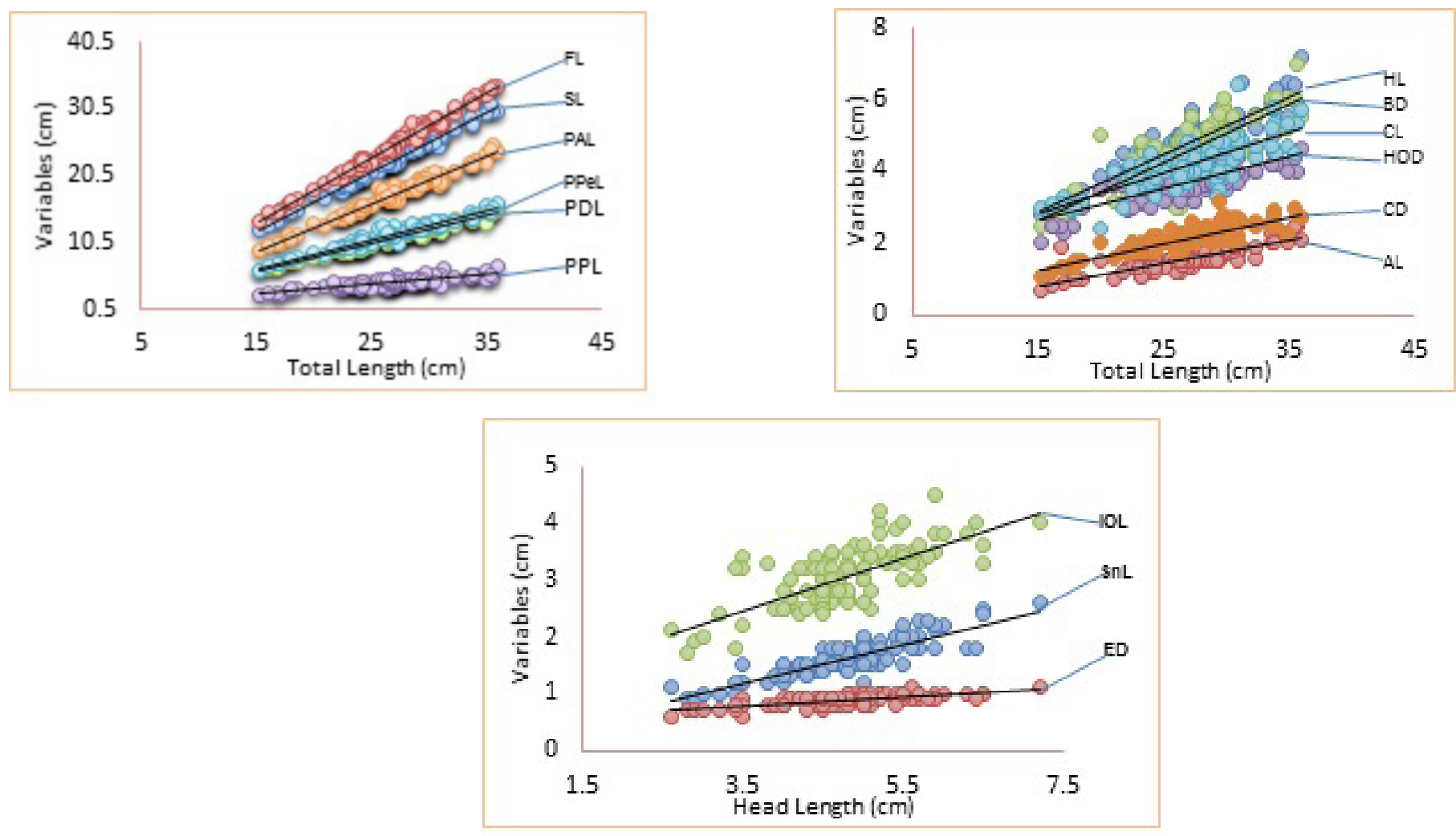

Figure 3. Graphs showing the relationship of TL and HL with different body parameters. 
Generally fish exhibit great sensitivity to environmental variables and show great morphological variability than other vertebrates ${ }^{11}$. Different habitats provide different ecological conditions which may cause different adaptations in morphological features of fish, therefore an important relationship exists between morphological and functional traits of fish and their ecological niches ${ }^{23,24}$. During early life stages, apart from genetic influence, morphology is dependent on environmental conditions ${ }^{25,26}$ therefore, environmental conditions also influence morphometric characters ${ }^{27}$. To determine the influence of genetic and environmental variables on the changing fish morphology, biologists categorize the morphometric characters on the basis of range differences into genetically, intermediate and environmentally controlled characters. According to ${ }^{14}$, the morphometric characters can be categorised on the basis of \% range difference into genetically $(<10 \%)$, intermediate (10-15\%) and environmentally $(>15 \%)$ controlled characters. In one of the studies ${ }^{28}$, while analysing the morphometric data of Tor putitora from foot hill section of Ganga, India found that 12 characters in relation to TL of fish were genetically controlled, 2 were intermediate and only 1 had been found to be environmentally controlled one. Similarly in relation to HL, 3 characters were found to be intermediate and 2 characters as environmentally controlled ones. In similar kind of studies by various workers ${ }^{29-34}$ there are varying degrees of environmentally, genetically and intermediate controlled characters in different fish species. During the present study, in percentage of TL of fish, 8 characters are genetically controlled, 4 are intermediate and none as environmentally controlled one. In percentage of $\mathrm{HL}$ of fish, 2 characters are environmentally controlled one, 1 character is in intermediate category and none in genetically controlled one. The morphometric studies on a fresh water cyprinid fish Cyprinus carpio from river Jhelum $^{33}$ Jammu and Kashmir, India, somehow correlates with the present study, wherein the results revealed that out of 18 morphometric characters in percentage of TL of fish, 3 characters were genetically controlled, 13 characters as intermediate and only 2 characters were environmentally controlled ones and in the percentage of HL of fish, out of 7 morphometric characters, 2 were found to be intermediate and 5 were found to be included in genetically controlled category. Generally it is seen that; the characters belonging to the environmentally controlled ones show maximum range of variation, the characters belonging to the genetically controlled ones show the minimum range of variation and the intermediate category of characters show the moderate range of variation ${ }^{35}$. The present study also confirms the statement as revealed by the high variance observed in case of IOL (V = 79.22) followed by SnL ( $\mathrm{V}=11.67)$ which are environmentally controlled characters and show maximum range of variance as compared to other morphometric characters. As clear from the results, since SnL and IOL are environmentally controlled characters and ED an intermediate character, therefore it can be concluded that the maximum influence of the environment will be on the variations in IOL and SnL followed by ED. Also it can be concluded that these characters in a particular species may vary from water body to water body depending upon their ecological conditions like nature of flow, bottom texture, habitat features and various other physico-chemical parameters. Since IOL, SnL and ED are the characters of head region of the fish, therefore it can also be concluded that head region of this fish is most susceptible part of variations with respect to environmental factors and therefore, can be helpful in solving taxonomic ambiguities among Schizothorax species.

Different workers revealed the varying degrees of correlation between various morphometric characters of fish with respect to their TL and HL. In one of the studies ${ }^{36}$ while studying the morphometric characters of Schizothorax spp. in river Lidder of Kashmir valley, India found a positive correlation of different morphometric characters with TL $(r \leq 0.98$ and $\mathrm{r} \leq 0.87)$. Another similar study ${ }^{37}$ also revealed the positive correlation of various body parameters with respect to TL of fish wherein it was found that $\mathrm{r}>0.888$ in case of Puntius sophore and $\mathrm{r}$ $>0.897$ in case of $P$. ticto, which also suggests symmetrical growth in relation to different body lengths. Similar kind of results were also obtained during the present study wherein, it is found that in percentage of TL of fish, the ' $r$ ' value ranged from 0.770 to 0.995 ; and in the percentage of HL, the ' $r$ ' ranged from 0.706 to 0.859 , which suggests the high positive correlation of body parameters with respect to TL and HL. This also indicates that all the dependable characters increase in direct proportion to each other. During the present study, as revealed by the regression analysis, the maximum growth was obtained for FL in proportion to TL $(b=0.9664)$ followed by SL $(b=0.8876)$ and the minimum growth was obtained for $\mathrm{AL}(\mathrm{b}=0.0655)$. In a similar kind of regression analysis by ${ }^{38}$ on the S. plagiostomus and S. esocinus in Lidder river, Kashmir, wherein the maximum growth in case of $S$. plagiostomus with respect to TL was obtained for SL $(b=0.8538)$ and the minimum for pre pectoral length $(\mathrm{PPL})(\mathrm{b}=0.1648)$ and the maximum growth in case of $S$. esocinus with respect to TL was obtained for SL $(b=0.9080)$ and minimum for maximum body depth ( $b$ $=0.1730)$. Somehow similar kind of results were also obtained by different workers ${ }^{29,39-43}$ in similar kind of analysis. Since for the biological and taxonomic studies of fish, morphometric measurements and their statistical relationship is very much imperative $e^{44,45}$ as the morphological variation is the outcome of their adaptive strategies to different environments. Since for any biological trait to develop, there is influence of both genes as well as environment. In that very perspective, it can be concluded from our study that morphometric characters of the head region of $S$. labiatus are most susceptible to change 
with respect to environmental variables. Therefore maximum variation may be seen in case of head region in S. labiatus. As per the available literature, little amount of work has been done regarding the morphometric analysis of S. labiatus especially in the Vishav stream. Therefore the present findings will provide a baseline data for taxonomists and fishery biologists in rectifying the morphotaxonomic ambiguities of Schizothorax spp. in general and S. labiatus in particular, which are being faced during their identification process. Since as per our findings, most of the characters were genetically controlled and only one as purely environmentally controlled. Therefore, it also gives an indirect indication that Vishav stream is somehow still undisturbed from the environmental point of view.

\section{Acknowledgments}

The authors are highly thankful to the Head, Department of Zoology, University of Kashmir for providing necessary laboratory facilities to carry out this research work, the Research Fellowship provided by the University of Kashmir during the course of Ph.D. to the first author is also highly appreciated.

\section{References}

1. Nayman WH. Growth and ecology of fish population. J Anim Ecol. 1965; 20:201-19.

2. Langer S, Tripathi NK, Khajuria B. Morphometric and meristic study of golden Mahaseer (Tor putitora) from Jhajjar stream (J and K), India. Res J Anim Vet Fishery Sci. 2013; 1(7):1-4.

3. Vladykov VD. Environmental and taxonomic characters of fishes. Trans Roy Can Inst. 1934; 20:99-140.

4. McHugh JL. Geographic variation in the Pacific herring. Copeia. 1954; 1954(2):139-51. https://doi.org/10.2307/1440334

5. Allendorf FW, Ryman N, Utter F. Genetics and fishery management: Past, present and future in population genetics and fisheries management. Seattle, WA and London: University of Washington press; 1987. p. 1-20.

6. Wimberger PH. Plasticity of fish body shape. The effects of diet, development, family and age in two species of Geophagus (Pisces: Cichlidae). Biological Journal of the Linnean Society. 1992; 45(3):197-218. https://doi.org/10.1111/j.1095-8312.1992 tb00640.x

7. Hossain MA, Nahiduzzaman M, Saha D, Khanam MU, Alam MS. Landmark-based morphometric and meristic variations of the endangered Carp, Kalibaus labeo calbasu, from stocks of two isolated rivers, the Jamuna and Halda, and a hatchery. Zoological Studies. 2010; 49(4):556-63.

8. Hourston AS. Homing by Canada's west coast herring to management units and divisions as indicated by tag recoveries. Canadian Journal of Fisheries and Aquatic Sciences. 1982; 39(10):1414-22. https://doi.org/10.1139/f82-190
9. Iles TD, Sinclair M. Atlantic herring: Stock discreteness and abundance. Science. 1982; 215(4533):627-33. PMid: 17842372. https://doi.org/10.1126/science.215.4533.627

10. Hammami I, BaHrI-Sfar L, Kaoueche M, Grenouillet G, Lek S, Kara MH, Ben Hassine OK. Morphological characterization of striped seabream (Lithognathus mormyrus, Sparidae) in some Mediterranean lagoons. Cybium. 2013; 37(1-2):27-139.

11. Thompson JD. Phenotypic plasticity as a component of evolutionary change. Trends in Ecology and Evolution. 1991; 6(8):246-9. https://doi.org/10.1016/0169-5347(91)90070-E

12. Begg GA, Friedland KD, Pearce JB. Stock identification and its role in stock assessment and fisheries management: an overview. Fisheries Research. 1999; 43(1-3):1-8. https://doi.org/10.1016/ S0165-7836(99)00062-4

13. Tandon KK, Johal MS, Bala S. Morphometry of Cirrhinus reba (Hamilton) from Kanjli wetland, Punjab, India. Panjab University Research Journal (Science). 1993; 43(1-4):73-8.

14. Johal MS, Tandon KK, Sandhu GS. Mahseer in Lacustrine Waters, Gobindsagar Reservoir. Morphometry of Tor putitora. Mahseer the Game Fish, Nautiyal, P. (Ed.). Dehradun, Rachna, Srinagar, Garhwal: Jagdamba Prakashan Publisher; 1994. p. 67-85.

15. Mir JI, Shabir R, Mir FA. Length-weight relationship and condition factor of Schizopyge curvifrons (Heckel, 1838) from River Jhelum, Kashmir, India. World Journal of Fish and Marine Sciences. 2012; 4(3):325-9.

16. Hajam RA, Hamid A, Ahmad DN, Bhat SU. Morphometric analysis of Vishav drainage basin using Geo-spatial Technology (GST). International Research Journal of Geology and Mining. 2013; 3(3):136-46.

17. Talwar PK, Jhingran AG. Talwar PK, Jhingran AG. Inland fishes of India and adjacent countries. 1991.

18. Mirza MR. A contribution to the systematics of the Schizothoracine fishes (Pisces: Cyprinidae) with the description of three new tribes. Pakistan Journal of Zoology. 1991; 23:339-41.

19. Kullander SO, Fang F, Delling B, Ahlander E. The fishes of the Kashmir Valley. River Jhelum, Kashmir Valley. Impacts on the aquatic environment. Goteborg: Swedmar; 1999. p. 99-167.

20. Hoden MJ, Raitt DF. Manual of fisheries science. Part 2. Methods of resource investigation and their application. FAO Fish Tech Pap. 1974; 115:1-214.

21. Jayaram KC. Freshwater fishes of India, Pakistan, Bangladesh, Burma and Sri Lanka. 1981. p. 475.

22. Allen GR. Toxotes kimberleyensis, a new species of archerfish (Pisces: Toxotidae) from fresh waters of Western Australia. Records-Australian Museum. 2004; 56(2):225-30. https://doi.org /10.3853/j.0067-1975.56.2004.1423

23. Price SA, Holzman R, Near TJ, Wainwright PC. Coral reefs promote the evolution of morphological diversity and ecological novelty in labrid fishes. Ecology Letters. 2011; 14(5):462-9. PMid: 21385297. https://doi.org/10.1111/j.1461-0248.2011.01607.x

24. Farre M, Tuset VM, Maynou F, Recasens L, Lombarte A. Geometric morphology as an alternative for measuring the diversity of fish assemblages. Ecological Indicators. 2013; 29:15966. https://doi.org/10.1016/j.ecolind.2012.12.005 
25. Ryman N, Lagercrantz UL, Andersson L, Chakraborty R, Rosenberg R. Lack of correspondence between genetic and morphologic variability patterns in Atlantic herring (Clupea harengus). Heredity. 1984; 53(3):687-704. https://doi .org/10.1038/hdy.1984.127

26. Cheverud JM. A comparison of genetic and phenotypic correlations. Evolution. 1988; 42(5):958-68. PMid: 28581166. https://doi.org/10.2307/2408911

27. Swain DP, Foote CJ. Stocks and chameleons: The use of phenotypic variation in stock identification. Fisheries Research. 1999; 43(13):113-28. https://doi.org/10.1016/S0165-7836(99)00069-7

28. Bhatt JP, Nautiyal P, Singh HR. Racial structure of Himalayan mahseer, Tor putitora (Hamilton) in the river Ganga between Rishikesh and Hardwar. Indian Journal of Animal Sciences. 1998; 68(6):587-90.

29. Johal MS, Negi RK, Negi T. Age and growth of golden mahseer Tor putitora from Pong reservoir, Himachal Pradesh, India. Him J Env Zools. 2003; 17(2):17-29.

30. Negi RK, Negi T. Analysis of morphometric characters of Schizothorax richardsonii (Gray 1832) from the Uttarkashi District of Uttarakhand State, India. Journal of Biological Sciences. 2010; 10(6):536-40. https://doi.org/10.3923/jbs.2010.536.540

31. Ujjania NC, Kumar G, Langar RK, Krishna G. Biometric studies of mahseer (Tor tor. Ham. 1822) from Bari talab (Udaipur), India. International Journal of Innovations in Bio-Sciences. 2012; 2(3):38-141.

32. Vase VK, Reddy DA, Choudhury SR, Balakrishna $\mathrm{CH}$, Satyanaryana Y, Nagesh TS, Das SK. Morphometry and meristic counts of Bombay duck, Harpodon nehereus (Hamilton, 1822) along Sunderban region of West Bengal, India. Proceedings of the International Academy of Ecology and Environmental Sciences. 2014; 4(3):95-105.

33. Bhat MA, Mohammad N, Masarat S. Morphometric characters of freshwater fish Cyprinus sp. collected from River Jhelum, Kashmir. International Journal of Innovative Research in Advance Studies. 2016; 3(4):117-20.

34. Maji D, Pradhan A, Bhattacharya S, Mahapatra BK. Morphomeristic characteristics of a rare species Synaptura Commersonnii (Lacepede, 1802) from North-East coast of India, West Bengal. International Journal of Fisheries and Aquatic Studies. 2016; 4:237-41.

35. Krishand NR, Tarana N. Analysis of morphometric characters of Schizothorax richardonii (Gray, 1832) from the Uttarkashi District of Uttrakhand State, India. Journal of Biological Sciences. 2010; 10(6):536-40. https://doi.org/10.3923/jbs.2010.536.540
36. Bhat FA, Yousuf AR, Balkhi MH, Mahdi MD, Shah FA. Lengthweight relationship and morphometric characteristics of Schizothorax spp. in the River Lidder of Kashmir. Indian Journal of Fisheries. 2010; 57(2):73-6.

37. Ahmad S, Hussain MA, Alam MM. Morphometric relationships and condition factors of two freshwater barbs, Puntius sophore and Puntius ticto from the Padma river of Bangladesh. Trends in Fisheries Research. 2013; 2(3):15-9. https://doi .org/10.12966/fbls.03.04.2014

38. Bhat A., Balkhi, MH, Najar AM, Yousuf AR. Distribution pattern, density and morphometric characteristics of Shizothoracines (Snow trout) in Lidder river, Kashmir. The Bioscan. 2013; 8(2):363-9.

39. Bagenal TB, Tesch FW. Age and growth (Methods for Assessment of Fish Production in Fresh Waters). T. Bagenal, Ed. Blackwell Scientific Publications; 1978. p. 101-36.

40. Hoque MA, Hossain MA. Length-weight relationship and condition factor of the cat fish Mystus vittatus (Bloch) (Cypriniformes: Bagridae). University Journal of Zoology, Rajshahi University. 1992; 10:113-4.

41. Froese R. Cube law, condition factor and weight-length relationships: History, meta-analysis and recommendations. Journal of Applied Ichthyology. 2006; 22(4):241-53. https://doi .org/10.1111/j.1439-0426.2006.00805.x

42. Alam MM, Jahan SN, Hussain MA, De M, Goutham-Bharathi MP, Magalhaes AB, Mazlan AG, Simon KD. Length-length relationship, length-weight relationship and condition factor of freshwater fish species of Bangladesh. Aquaculture, Aquarium, Conservation and Legislation. 2013; 6(5):498-509.

43. Sharma NK, Mir JI, Pandey N, Singh R. Morphometric and meristic characteristics of Birdi Loach, Botia birdi (Chaudhuri, 1909) from a Tributary of Indus Basin, Jammu and Kashmir, India. World Journal of Fish and Marine Sciences. 2014; 6(3):262-6.

44. Gharaei A. Morphometric and meristic studies of snow trout Schizothorax zarudnyi (Nikolskii, 1897) as a threatened endemic fish. World Journal of Fish and Marine Sciences. 2012; 4(4): 426-9.

45. Poria M, Nouri F, Ghanbary K, Heshmatzad P. Interrelationship between morphometric variables and body weight Capoeta trutta (Heckel, 1843) evaluated by path analysis in Gamasiab River of Kermanshah Province, West of Iran. World Journal of Fish and Marine Sciences. 2013; 5(6):674-9. 